\title{
Solutions for the disposal of industrial and rain wastewater of transport enterprises in Moscow
}

\author{
Galina Varyushina ${ }^{1 *}$ \\ ${ }^{1}$ Moscow State University of Civil Engineering, Yaroslavskoye shosse, 26, Moscow, Russia, 129337
}

\begin{abstract}
The article gives results of the surveys water management systems, auto repair companies, bus compamies, taxis, fleets of trucks, production and technical enterprises. Studied technological processes of primary production: cleaning engines, flushing of radiators and parts of batteries, testing of fuel tanks, cleaning of parts and units, exterior washing and painting of motor vehicles. There were carried out field examinations of local industrial wastewater treatment facilities industrial wastewater and onsite construction runoff, the laboratory-production work to identify quantitative and qualitative indicators of the incoming and treated effluents, including petroleum products, suspended matter, salinity, synthetic surfactants, heavy metals etc. Proposed sustainable solutions for the improvement of the work of treatment facilities of rain sewage by mechanical and physical and chemical methods, including horizontal sand catchers, septic tanks - oil separator, a cascade of pressure filters with granular mineral over-loading and high-performance sorption materials, the effectiveness of treatment meets the requirements of water for its re-use for technical needs, and discharge to water bodies.
\end{abstract}

\section{Introduction}

The problem of disposal of industrial and rain wastewater of truck companies due to the continuous increase in the number of cars that consider as high toxic sources of pollution both air and water basins of Moscow city.

The main factors arising from the operation of various types of vehicles and driving to the negative impact on the atmosphere and hydrosphere of the city include:

- Aging transport that fail to meet ecological requirements, which leads to the fact that road transport is the main pollutant of the atmosphere, contributing more than $80 \%$ of all emissions;

- Low-quality motor fuels and lubricants;

* Corresponding author: nocviv@mgsu.ru 
- decrease of the capacity of the road network during peak times, as vehicles moving with low speed, a lot of maneuvering, the engines are stressed and, consequently, increases the amount of products of combustion of motor fuel and increased wear of the tread rubber tyres of cars, tire dust, which contains carcinogenic substances $(\mathrm{N}$ nitrosamines) and benzopyrene, flushed by storm water;

- contaminants (more than 200 types, in particular, carbon monoxide (CO), oxides of nitrogen $\left(\mathrm{NO}_{\mathrm{x}}\right)$ and sulfur $\left(\mathrm{SO}_{2}\right)$, polycyclic aromatic hydrocarbons (benzopyrene $\left(\mathrm{C}_{20} \mathrm{H}_{12}\right)$, hydrocarbons, halogen-containing, phenols, aldehydes, and ketones of aliphatic, alkylaromatic esters, heavy metals, sulfur-containing deposited substances, soot, etc.) received from vehicles in the atmospheric air, soil-and water $\mathrm{Wu}$ in the movement, storage, launching, cleaning, maintenance and repair, as well as disposing of the car and its elements.

\section{Features of transport enterprises sewage}

Modern dynamics of the growth rate of the car amount leads to the need to develop organizational and technical solutions aimed at minimizing the negative impact of the functioning transport enterprises (TE) on the environment of the city. Depending on the functional purpose of TE installed a water consumption rate of drinking and industrial water for production needs and requirements for its sanitary and chemical composition, as well as the conditions of discharge of industrial wastewater in municipal drainage network.

Under the new Rules of water supply and sanitation, approved by Decree No. 644 dated 29.11.2013 of the Russian Government changed the standard indicators of General properties of wastewater and concentrations of pollutants in wastewater are allowed to discharge to a centralized sewerage system. In particular, the maximum permissible concentration of dissolved petroleum products is $10 \mathrm{mg} / \mathrm{l}$, salinity $-3,000 \mathrm{mg} / \mathrm{l}$, fats -50 $\mathrm{mg} / \mathrm{l}$, volatile organic compounds (toluene, benzene, acetone, methanol) $20 \mathrm{mg} / \mathrm{l}$, suspended solids $-300 \mathrm{mg} / 1$, synthetic surfactants $-10 \mathrm{mg} / \mathrm{l}$ and phenols $0.25 \mathrm{mg} / 1$ [1-3]. In addition, the new Rules provided production processes, the implementation of the enterprise central systems are required to have local treatment facilities and discharge of treated wastewater. These businesses include motor, in production processes, which formed oil, acid, alkali, heavy metal ions, organic solvents, volatile organic compounds, synthetic surfactants, organic chlorine compounds deposited mineral inclusions hydraulic size greater than 2 $\mathrm{mm} / \mathrm{s}$, floating substances with particle size more than $20 \mathrm{~mm} / \mathrm{s}$. To achieve the modern requirements to the wastewater before discharge into the centralized Sewerage system, it seems advisable to collect and diversion of industrial runoff of TE to separate the Sewerage scheme and subsequent local cleaning each thread. As you know, it processes all the water drinking and technical water on the TE is used for household needs and showers, sanitary washing of floors in buildings and wash works to clean the territory, in garage, technological processes for the repair and maintenance of motor vehicles and feeding of circulating technical water supply systems and boilers [4-7].

Peculiarity of formation of the industrial wastewater is a complex of TE with a wide technological base is a multi-component composition of wastewater generated in the basic processes:

- $\quad$ Paint shop for painting body parts with the use of the painting chambers, strainers and mechanical treatment of water for removal of paints, varnishes and solvents and water reuse; 
- Workshop for electroplating component elements of the vehicles with local treatment from the armed removal of heavy metals (copper, chromium, zinc, iron, etc.);

- Workshop for cleaning of engines, chassis and components of vehicles of cleaning solutions and their preparation for repair and testing on the stands with a working system of multiple use of cleaning agents and disposal of petroleum products and sediments;

- Workshop for repair and service of batteries with internal structures to neutralize acidic wastewater;

- cooling of technological equipment;

- Production areas for oil change and mechanical filters with the disposal of effluent in onsite wastewater treatment plant for industrial and rain waste water;

- Workshop external washing of vehicles and their salons with turnaround system of technical water supply;

- $\quad$ surface waste water (rainwater, snowmelt, snow) from the roofs of buildings and site of $\mathrm{TE}$, parsed samples introduced for on-site wastewater treatment plants prior to their diversion into the municipal rainwater drainage networks.

Studies of water management systems on the TE of the city of Moscow are performed by the laboratory processing the city, industrial and rain sewage and sludge of "Institute MosvodokanalNIIproekt" from 1990 to the present time that allows you to organize and summarize quantitative and qualitative indicators of efficiency of use of water and operation of local treatment facilities. The results of surveys of TE indicate that the effect of sewage water purification from dissolved organics, paint strainers cameras the methods of sedimentation and filtration does not satisfy the requirements of the water or its reuse in the paint shops, and any discharge to a centralized sewerage system. For the removal of contaminants needs to upgrade the existing technological scheme of water purification by applying highly efficient coagulants and flocculants with the purification of the mineral sorbents. Evaluating the work of treatment facilities to remove chromium and other heavy metals Metalworking shops, it was established that widespread chemical and electrocoagulation methods show the effect of treatment of $72-85 \%$ recovery of chromium, forming a hard residue neutralizes and spending a significant amount of power [8-12].

As practice shows, the best way to clean chrome wastewater is ion-exchange method, the essence of which is to exchange part of ions in the result of which purified water meets the requirements of water for reuse in the shops for metal processing. The most contaminated streams of industrial wastewater on TE contain oil products, suspended substances and settled, scale, caustic soda, soda ash are the wastewater plant washing parts and assemblies of cars is a necessary operation before the implementation of office repair and maintenance $[13,14]$. For the purpose of rational use of valuable raw materials for TE provides multiple use of cleaning solutions consisting of high concentrated solutions of soda ash, trisodium phosphate and sodium tripolyphosphate, in the recirculating system with the preliminary removal of oil in emulsified and dissolved condition. The most widely methods of neutralization of stable emulsions by demulsifiers resulting in delamination of the suspension and, as a consequence, sediments and floating oil film. The removal efficiency of oil is $65-90 \%$ [15-18].

The most water-intensive manufacturing process TE should include mechanized and manual cleaning of vehicles carried out daily according to the sanitary-epidemiological requirements and regulations of the contents of the vehicle. Depending on the car category, its dimensions, the technical condition of the roads, season of year and type of applied anti- 
icing agents in a wide range of change of concentration of pollution of wastewater from the car wash: settling and suspended solids, mineral oils, gasoline and diesel fractions, full $\mathrm{BOD}, \mathrm{COD}$, detergents, sulfates, chlorides, $\mathrm{pH}$. It should be noted that wastewater from the car wash are characterized by a high degree of bacterial material contamination, in this connection, according to the sanitary requirements of the technological scheme should be included bactericidal installation for disinfection of treated wastewater used in the system of technical water supply local company $[1,4,7]$.

Based on the results of chemical analyses of initial and treated waters obtained in the course system of optical monitoring of the efficiency treatment of the complexes made, we can conclude that in the original water act of technogenic contamination of the basic technological processes of TE, as evidenced by the excess of concentration of oil products, detergents and other substances. Table 1 shows the data for the control of wastewater main production processes of TE provided in accordance with industry technical standards for all enterprises that perform work on maintenance, repair and service of vehicles.

Table 1. Transport enterprises sewage features

\begin{tabular}{|c|c|c|c|c|c|c|c|c|}
\hline \multirow{2}{*}{$\begin{array}{l}\text { Type of } \\
\text { process }\end{array}$} & \multicolumn{8}{|c|}{ Concentration $[\mathrm{mg} / \mathrm{l}]$} \\
\hline & TSS & Petrochem & $\mathrm{pH}$ & Sulphates & Chlorides & \begin{tabular}{|l|} 
synthetic \\
surfactants
\end{tabular} & $\mathrm{Cr}$ & COD \\
\hline $\begin{array}{l}\text { Car parts } \\
\text { painting }\end{array}$ & $\begin{array}{l}1400- \\
2300\end{array}$ & $50-380$ & $\begin{array}{c}7.5- \\
9.0\end{array}$ & $\begin{array}{l}970- \\
1600\end{array}$ & $\begin{array}{c}2400- \\
3900\end{array}$ & $25-40$ & $\begin{array}{l}0.05 \\
-2.4\end{array}$ & $\begin{array}{c}1430- \\
2600\end{array}$ \\
\hline $\begin{array}{c}\text { Metal } \\
\text { processing }\end{array}$ & $\begin{array}{c}630- \\
820\end{array}$ & $4.6-10.5$ & $\begin{array}{c}6.2- \\
7.1\end{array}$ & $\begin{array}{c}120- \\
230\end{array}$ & $\begin{array}{c}220- \\
460\end{array}$ & $1.5-3.0$ & $\begin{array}{c}310- \\
400\end{array}$ & $\begin{array}{c}600- \\
830\end{array}$ \\
\hline $\begin{array}{c}\text { Engine } \\
\text { washing }\end{array}$ & $\begin{array}{c}3000- \\
5200\end{array}$ & $\begin{array}{c}2600- \\
5600\end{array}$ & $9-12$ & $\begin{array}{c}2100- \\
3400\end{array}$ & $\begin{array}{c}4100- \\
4700\end{array}$ & $\begin{array}{c}260- \\
390\end{array}$ & $1-10$ & $\begin{array}{c}1300- \\
2800\end{array}$ \\
\hline $\begin{array}{c}\text { Batteries } \\
\text { maintenan } \\
\text { ce }\end{array}$ & $\begin{array}{c}110- \\
230\end{array}$ & $12-35$ & $3-11$ & $\begin{array}{c}250- \\
400\end{array}$ & $\begin{array}{c}650- \\
920\end{array}$ & $0.5-2.0$ & $\begin{array}{c}0.1- \\
0.5\end{array}$ & $\begin{array}{c}55- \\
83\end{array}$ \\
\hline $\begin{array}{c}\text { Car } \\
\text { washing }\end{array}$ & $\begin{array}{l}870- \\
3200\end{array}$ & $100-200$ & $7-9$ & $\begin{array}{c}190- \\
320\end{array}$ & $\begin{array}{c}590- \\
740\end{array}$ & $58-170$ & $1-5$ & $\begin{array}{c}240- \\
580\end{array}$ \\
\hline $\begin{array}{l}\text { Surface } \\
\text { sewage }\end{array}$ & $\begin{array}{c}380- \\
1600\end{array}$ & $35-180$ & $7-8$ & $50-120$ & $\begin{array}{c}260- \\
410\end{array}$ & $3-18$ & $\begin{array}{c}0.5- \\
1.0\end{array}$ & $\begin{array}{c}350- \\
560\end{array}$ \\
\hline
\end{tabular}

\section{Solutions for wastewater treatment}

Collection and transportation of industrial wastewaters is carried out by a separate scheme with local treatment plants and reuse of treated water for technical needs. To clean storm water and wastewater from washing vehicles there were process solutions and project documentation, relevant for nowadays environmental and sanitary requirements, according to which in Moscow and Moscow region, there were built dozens of treatment systems in bus and tram depots, fleets and taxi companies, repair bases, and road construction equipment. Technological scheme of purification of rainwater sewage includes the following facilities mechanical, physical, and chemical treatment: horizontal sand traps, oil traps, clarifiers, three-stage pressure filters with granular mineral feed, and tertiary treatment facilities [5-8]. Typical pollution runoff include suspended solids, oil products, sulphates, chlorides and organic material of natural origin washing into catchment areas of rain and melt waters. To achieve the fisheries management requirements of the discharge rain sewage into water objects of Moscow there were developed projects that built facilities for deep cleaning of the cumulative type. 
A method of forming and cleaning runoff is as follows: collection, averaging and cleaning exposed to the entire volume of rainwater falling on the territory of the catchment. Calculation of the quantity of rainwater runoff from 1 ha of the catchment is determined by the results of observations of meteorological service in the area for producing the monitoring of quantitative parameters of precipitation. Systematization and analysis of these data allows determining the quantity of fallen rain, their intensity, frequency and duration. Rain wastewater is collected in sewers inside drains through grids located in the territory in accordance with the vertical layout and go to the underground regulating reservoir.

Regulatory capacity is composed of rectangular sections into which the polluted wastewater coming consistently through the overflow window, located in the upper part of the section. For their abduction in gravity mode wastewater treatment plant located in the lower areas of the catchment, with the low grid determining the filling of the regulating tanks. After passing through the grids located in the main and after filling of the regulating tanks by the estimated volume of one rain, non-nominal volume of $5 \%$, overflows to urban collector or pond. Facility design eliminates the possibility of discharge into reservoirs of oil slicks, dropped out sediment and other coarse impurities.

Industrial water mechanical cleaning method of settling goes within $2-3$ days, after which the clarified effluent is directed to the physical-chemical treatment including a cascade of three successive series pressure filters with mineral filter and sorption materials.

The main criteria for the filters include the following: developed specific surface of the grains, large porosity and dirt-holding capacity, mechanical strength, low friability, high sorption capacity, regeneration ability without the use of reagents in the process of operation, the possibility of environmentally friendly disposal after the complete exhaustion of the initial properties, long life cycle and low cost $[12,14,15]$.

During the research, it was found that the most effective filter materials meeting the above requirements should be classified as quartz sand, basalt, zeolite, crushed anthracite and haydite chips (fractional composition of $1-2 \mathrm{~mm}$ ). As sorption material there were recommended fine-grained activated carbon of various grades. High sorption capacity of activated carbons leads to a profound purification of industrial wastewater of trace amounts of suspended solids, dissolved oil products, residues, heavy metal salts, synthetic toxicants. Rinsing in counter-current mode of filter and sorption materials purified water accumulated in the collecting tank leads to the effective removal of dirt from the surface of the grains and of the interporous space. Contaminated rinsing water is returned to the regulating tank for further settling and post-treatment on pressure filters.

Based on the results of laboratory and production control treatment plants during the different seasons of the year, the efficiency of treatment of the complexes corresponds to the design performance, subject to the rules of operation are developed and agreed in the project documentation. The program of laboratory and production control and monitoring of the effectiveness of local treatment facilities is developed by the environmental service of the company based on the environmental regulations and demands to the used technological equipment installed by the manufacturer. The program includes the following sections: list of studied indicators of the composition of water and sediments; sampling frequency; sampling; quantitative and qualitative characteristics of the resulting sludge. Analysis of the main indicators of the structures with regular observations of the processes of industrial wastewater purification allows making fast technical and organizational solutions aimed at improving the efficiency of contaminants removal and minimizing energy consumption for the operation of the facilities. 
Table 2 shows the performance of rain sewage treatment facilities of tram depot, located in the Northwestern administrative district of Moscow.

Table 2. The efficiency of cleaning of storm water at the treatment facilities of the tram depot

\begin{tabular}{|l|l|l|l|}
\hline Indicators & $\begin{array}{l}\text { Initial concentration } \\
{[\mathbf{m g} / \mathbf{l}]}\end{array}$ & $\begin{array}{l}\text { Treated water } \\
\text { concentration }[\mathbf{m g} / \mathbf{l}]\end{array}$ & $\begin{array}{l}\text { Discharge limits } \\
{[\mathbf{m g} / \mathbf{l}]}\end{array}$ \\
\hline Aluminum & 3.557 & 0.023 & 0.04 \\
\hline BOD & 8.63 & 2.19 & 3.0 \\
\hline Suspended solids & 256.0 & 3.0 & 3.0 \\
\hline Iron & 9.714 & 0.047 & 0.1 \\
\hline Cadmium & 0.972 & 0,001 & 0.005 \\
\hline Manganese & 2.153 & 0.006 & 0.01 \\
\hline Copper & 1.067 & 0.001 & 0.001 \\
\hline Petrochemicals & 64.32 & 0.03 & 0.05 \\
\hline Nickel & 1.295 & 0.007 & 0.01 \\
\hline Total salts & 659.37 & 640.22 & 1000.0 \\
\hline pH & 7.5 & 7.3 & $6.5-8.5$ \\
\hline Lead & 2.689 & 0.002 & 0.006 \\
\hline $\begin{array}{l}\text { synthetic } \\
\text { surfactants }\end{array}$ & 5.732 & 0.005 & 0.01 \\
\hline Sulphates & 90.41 & & \\
\hline Chlorides & 207.83 & 83.62 & 100.0 \\
\hline COD & 42.65 & 190.54 & 300.0 \\
\hline Chromium +3 & 0.874 & 10.78 & 30.0 \\
\hline Chromium +6 & 0.163 & 0.019 & 0.07 \\
\hline Cyanides & 0,927 & 0.015 & 0.02 \\
\hline Zinc & 1.538 & 0.036 & 0.05 \\
\hline & & 0.008 & 0.01 \\
\hline
\end{tabular}

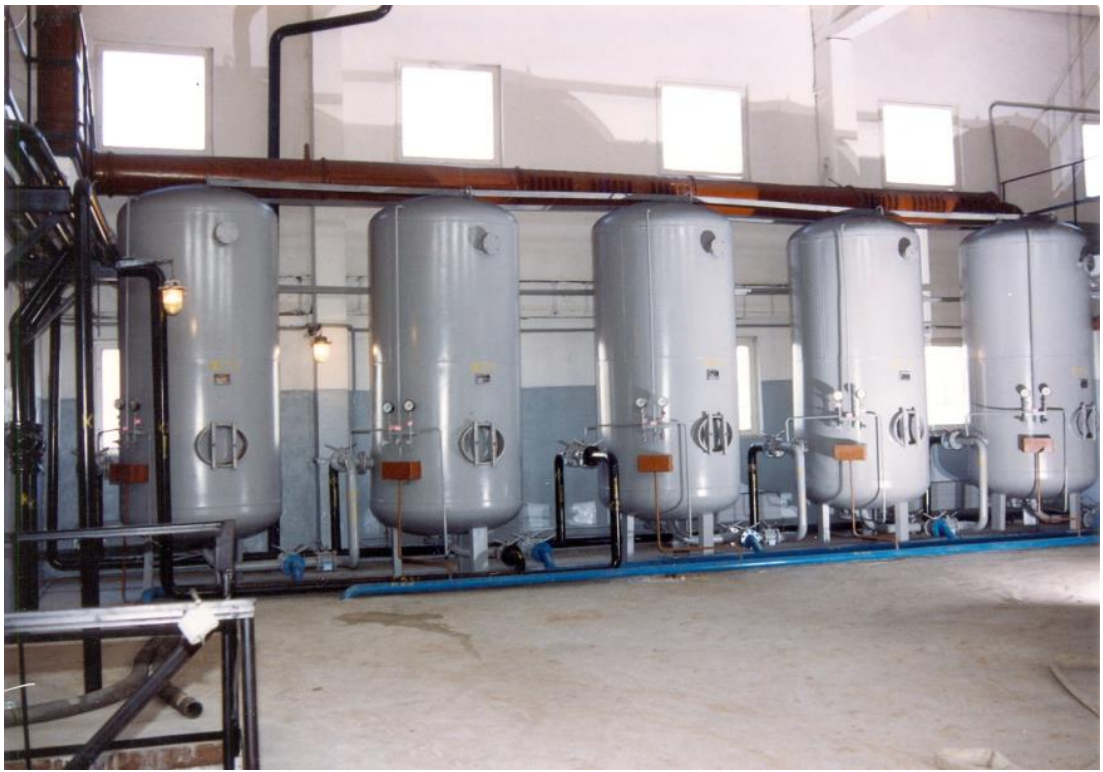

Fig. 1. Wastewater facilities for treatment of bus washing wastewater 
For disposal of industrial wastewater formed in water-intensive process of mechanized and manual cleaning of vehicles, the reverse process water supply system with reuse of treated water for car wash was developed. Technological solutions based on physical and chemical methods of water purification and processing of the resulting precipitate. On the first stage (oil trap), the process of gravity removal of coarse impurities and floating oil goes; on the second stage - filters with granular mineral downloads and germicidal lamps purification from emulsified oil and suspended solids to the requirements of water for reuse. For dewatering and collection of the resulting precipitate, there is a filter press and storage bin to export of filter cake for disposal twice a year. Fig. 1 shows the room of pressure filters of facilities for treatment of wastewater from bus washing, located in the Northern administrative district of the Moscow [19-20].

\section{Conclusions}

1. As the results of surveys of the water systems of the motor transport enterprise, it is necessary to continue improving the work of local treatment facilities of industrial sewage and rain wastewater on-site objects, as trucking companies continue to remain highly toxic man-made objects in both air and water basins of Moscow city.

2. There were treatment facilities developed for disposal of wastewater from washing vehicles of different categories: cars, trucks, buses, road and construction equipment.

3. There were high efficiency technology developed of treatment of industrial and rain wastewater of transport enterprises, to meet current regulations for discharge to water bodies.

\section{References}

1. E. Gogina, I. Gulshin, Pr. Eng., 117, 107-113 (2015)

2. A.G. Pervov, A.P. Andrianov, T.P. Gorbunova, A.S. Bagdasaryan, Petr. Chem., 55 (10), 879-886 (2015)

3. I. Gulshin, A. Kuzina, IJAER, 10, 21, 42618-42623 (2015)

4. A. Volkov, V. Chulkov, R. Kazaryan, M. Fachratov, O. Kyzina, R. Gazaryan, AMM, 580-583, 2281-2284, (2014)

5. N. Makisha, A. Kulakov, MATEC web of conferences, 112, 10018 (2017)

6. A.G. Pervov, A.P. Andrianov, E.B. Yurchevskiy, Petr. Chem., 55 (10), 871-878 (2015)

7. E. Gogina, A. Pelipenko, MATECCONF, 73, 03007 (2016)

8. V.N. Varapaev, S.A. Doroshenko, A.Y. Trotsko, A.V. Doroshenko, IJAER, 10, 21, 42588-42592 (2015)

9. N. Makisha, Pr. Eng., 165, 1092-1097 (2016)

10. O. Kuzina, E. Pankratov, V. Tkachev, MATECCONF, 86, 05023 (2016)

11. V. Orlov, A. Andrianov, AMM, 580-583, 2398-2402 (2014)

12. V.N. Varapaev, A.V. Doroshenko, I.Y. Lantsova, Pr. Eng., 153, 816-823 (2016)

13. N. Makisha, M.Yunchina, MATEC Web of Conferences, 106, 70016 (2017)

14. A.G. Pervov, A.P. Andrianov, DWT, 35 (1-3), $2-9$ (2011)

15. E. Gogina, I. Gulshin, AMM, 580-583, 2367-2369 (2014)

16. A. Volkov, O. Kuzina, Pr. Eng., 153, 838-843 (2016)

17. A.A. Volkov, A.V. Sedov, P.D. Chelyshkov, D.A. Lysenko, A.V. Doroshenko, IJAER, 10, 22, 43269-43272 (2015) 
18. E. Gogina, I. Gulshin, Pr. Eng., 153, 189-194 (2016)

19. A.G. Pervov, A.P. Andrianov, V.A. Chukhin, R.V. Efremov, IJAER, 10, 22, $43517-$ 43525 (2015)

20. A. Kulakov, N. Makisha, MATEC Web of Conferences, 112, 10019 (2017) 